\title{
Temperature and movement measurements at a bergschrund
}

\author{
RUDOLF MAIR \\ Lawinenwarndienst, Amt der Tiroler Landesregierung, A-6010 Innsbruck, Austria \\ MichaEl KUHN \\ Institut für Meteorologie und Geophysik, A-6020 Innsbruck, Austria
}

\begin{abstract}
The highest, nearly stationary crevasse that occurs on most alpine glaciers is commonly called a bergschrund. It has often been believed to form when the main ice body below slides downward and thus separates from the thin, steep ice above, which is supposed to remain frozen to its bed. In order to verify or refute this assumption, temperatures and ice motion were recorded at several points in and around a bergschrund on Daunferner, a glacier in the Stubai Alps in Tyrol, Austria. Both measurements and observations indicated that the ice above the bergschrund was sliding as well and that the crevasse formed at a place where ice thickness, deformation and sliding velocity were markedly increasing.

At the same time a randkluft, i.e. a deep crevasse between the headwall and the glacier, was observed to open, clearly the result of ice flow and not due to melting as previously believed.
\end{abstract}

\section{INTRODUCTION}

Two features of alpine glaciers have challenged mountaineers and glaciologists alike: the so-called bergschrund and randkluft, both being nearly stationary crevasses that usually intersect the ice down to bedrock. While the randkluft separates rock and ice, the bergschrund opens between shallow and deep ice, often separating a steep ice wall from a flat part of a glacier.

That the two features bear names of fairly old German origin testifies to the fact that they first attracted Man's attention long before glaciology was born (Klebelsberg, 1948-49). Not only may randklufts appear, several meters deep, at the headwall of a glacier surrounded by rock, or on the fringe of glacier tongues, but they may also, on a smaller scale, separate avalanche cones from steep cliffs, or remnant snow patches from boulders. On all scales they were in the way of animals and humans, and on their smallest scale they were observed to be due to melting around hot rocks. The latter observation, however, was uncritically extrapolated to all scales of randklufts; it is shown in the present study that on the dekameter scale they can only be explained by basal sliding.

A bergschrund is a feature in the upper reaches of a glacier that is conspicuous from far away. It appears in many varieties and may have several physical causes. What seems to be common to all of them is a discontinuity of ice velocity both tangential to the surface and vertical. This implies that (i) the crevasse widens during the summer and (ii) the tangent of the ice surface below the crevasse is less inclined than that above, or in other words, the lower rim of the bergschrund has a faster vertical downward velocity than the upper rim. If there is sufficient space for it to develop fully, a bergschrund has a crescent shape, concave when looked at from below.

Several of them may be staggered one above the other on one slope. Usually they are continuous, but often they are made up of a series of separate, short, horizontal crevasses that are all arranged in a crescent shape.

There may be a bulge in the surface between two of them, or simply a discontinuity in surface slope, sometimes so faint as to appear to be only a parallel shift of the surface above and below.

Meltwater is observed to penetrate down to bedrock in a bergschrund, and the ice apron above the crevasse may be sliding or may indeed be frozen to the ground.

In order to investigate and quantify the common physical causes underlying all the features observed, above all to determine whether sliding or deformation, dynamics or thermodynamics prevails in the formation of bergschrunds and randklufts, a series of measurements was initiated at Daunferner, situated at $47^{\circ} \mathrm{N} 11^{\circ} 07^{\prime} \mathrm{E}$, in the Stubai Alps in Tyrol, Austria, at an altitude of approximately $3100 \mathrm{~m}$, in the spring of 1987 .

\section{PREVIOUS STUDIES}

Bergschrunds and randklufts have been investigated since the beginning of this century in a number of studies that have focused on various facets of this phenomenon. Three excellent recently published works deserve to be mentioned. Osborne (1983) described the characteristics of the bergschrund of an avalanche-cone glacier, some of 
which may appear also in the glacier treated here. Gardner (1987) concentrated on the weathering of headwalls in the freeze-thaw zone of Boundary Glacier and included references since 1900. Hanson and Hooke (1994) presented measurements of short-term velocity near a bergschrund on Storglaciären.

\section{THE SETUP OF THE EXPERIMENT}

The position of the bergschrund was determined by mechanically probing through the spring snowpack. It is illustrated in Figures 1 and 2, together with a minor bergschrund, the randkluft and the bordering rocks. The slope angles in Figure 2 are those at the end of the accumulation season, when the surface was sculptured by snowfall, avalanches and wind drift. They are still equal $\left(32^{\circ}\right)$ above and below the bergschrund because the ice was still dormant before it would slide and deform at a faster and differential pace in the extending flow of the melting season.

Ice temperature was measured with ten thermistors placed at various locations and depths down to $15 \mathrm{~m}$ as shown in Figures 2 and 3. The sensors were placed in boreholes of $2 \mathrm{~cm}$ diameter in May and June at a time when water subsequently filling in would freeze and attain the temperature of the surroundings. Thermistor output was read to hundredths of a degree but was

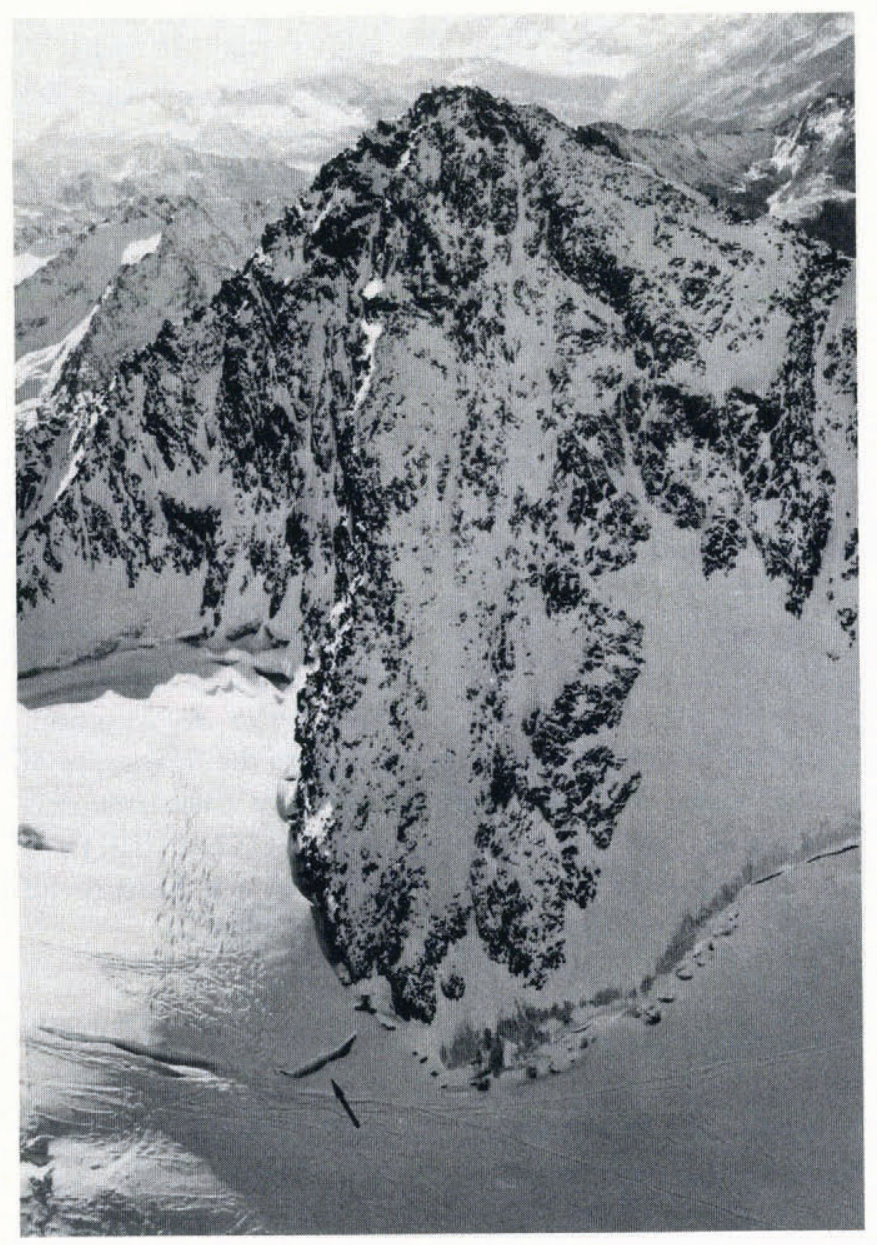

Fig. 1. Stubaier Wildspitze as seen from the north. The arrow is pointing at the main schrund (4 November 1987).

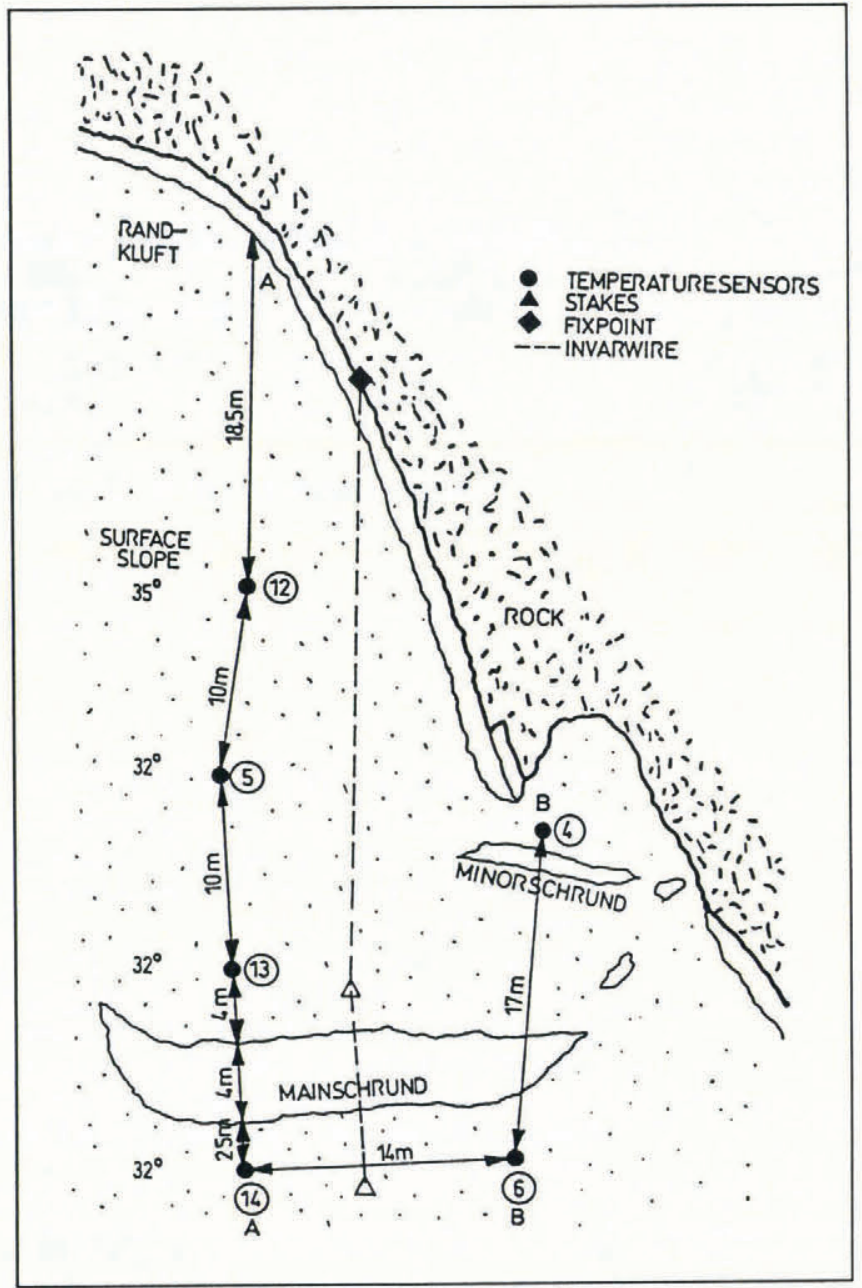

Fig. 2. General layout of crevasses and instrumentation. Circled numbers and capital letters refer to positions in Figure 3.

accepted to be accurate to one-tenth of a degree in both relative and absolute terms.

Figure 2 also shows the positions of one fix point in the headwall and of two stakes, one above and one below the bergschrund. An Invar wire was fixed to the rock and led to the upper stake, where it was attached to a so-called kryokinometer, an instrument with which the growing distance between the rock and the stake can be read off a dial that is turned as the wire spools off. The wire was made of Invar alloy, which has a thermal expansion coefficient of the order of $10^{-6}{ }^{\circ} \mathrm{C}^{-1}$. Thus, actual thermal expansion of the wire was less than the effects due to mechanical tension of the wire or deformation of the wooden stakes. The tangential movement of the stakes with the ice was of the order of centimeters per day.

Ice temperatures were recorded on 21 dates from June to December 1987, stake motion on nine dates from 2 August to 30 September 1987.

\section{ICE TEMPERATURES}

Table 1 summarizes the temperature records from a selected group of thermistors. From their positions, the sensors can be subdivided into three groups: four at shallow depths (Nos. 4, 6, 13 and 14, at 2-3 m), four near 


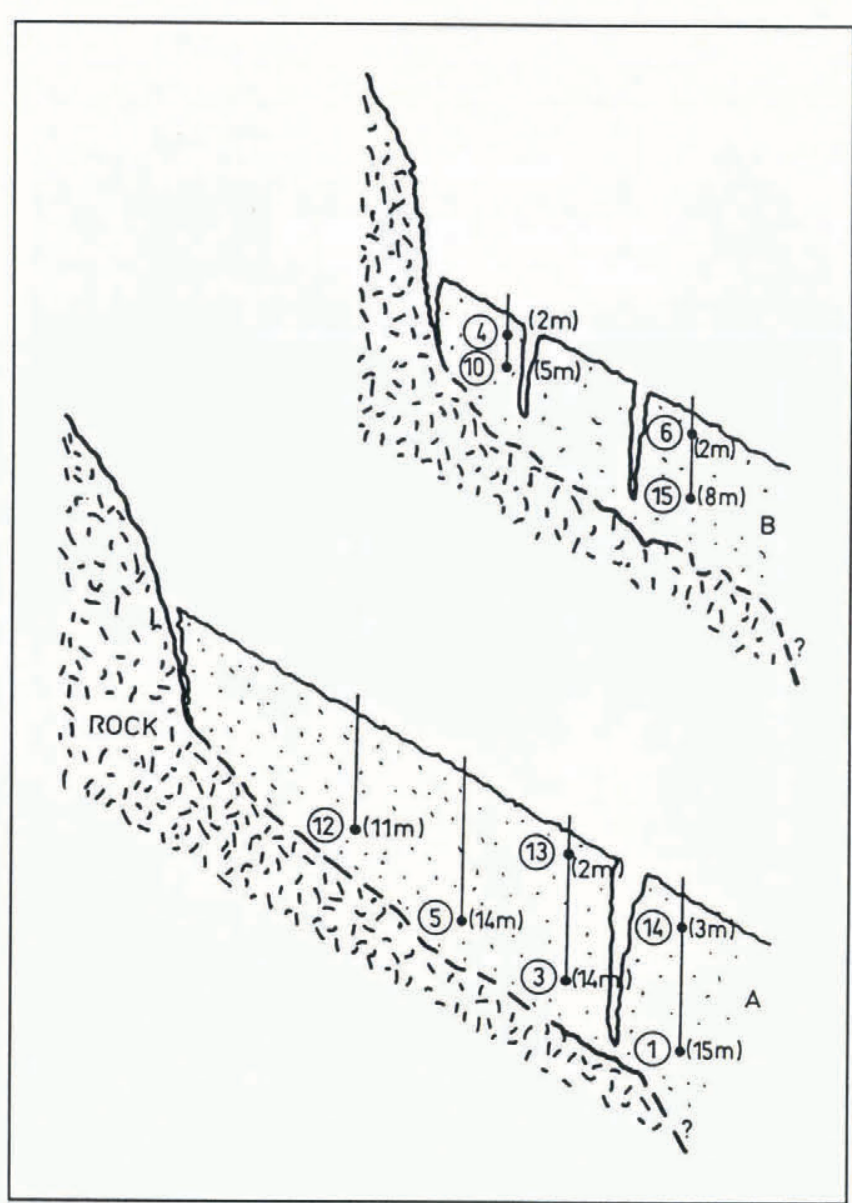

Fig. 3. Positions of temperature sensors. the bedrock (Nos. 5, 10, 12 and 15) and two at 14 or $15 \mathrm{~m}$ depth but still several meters above bedrock (Nos. 1 and 3). The first group reached the melting point in the first week of July, the second in early August and those at sufficient distance from both surface and bedrock stayed frozen all summer.

It is safe to say that both heat conduction and meltwater percolation reached the sensors of the first group, at shallow depth. As the second group was at depths ranging from 5 to $14 \mathrm{~m}$ below the surface, it is not certain whether conduction alone could have supplied enough heat to warm the ice up to melting point. More likely it was meltwater that had entered through the randkluft above and was flowing between bedrock and glacier. This was not possible for the deep sensors of the third group, which were several meters above bedrock and thus stayed below freezing. At elevations of 3000 $3600 \mathrm{~m}$, basically all the ice is temperate, i.e. at the pressure-melting point (Haeberli, 1976). However, a cold core in an otherwise temperate glacier is not uncommon in places where solid ice is exposed at the beginning of the accumulation season. Markl and Wagner (1978) observed ice temperatures of $-1.5^{\circ} \mathrm{C}$ at depths below $5 \mathrm{~m}$ near the equilibrium line of Hintereisferner. In the present case, the low temperatures of sensors 1 and 3 may also be an indication that the bergschrund, to which they had a horizontal distance of only 2.5 and $4 \mathrm{~m}$, respectively, had been open in the early part of winter. What is important in the context of ice movement is the fact that there was meltwater flowing between the bedrock and the ice apron above the bergschrund (Mair, 1988).

Table 1. Ice temperatures $\left({ }^{\circ} \mathrm{C}\right)$ at Daunferner, 1987

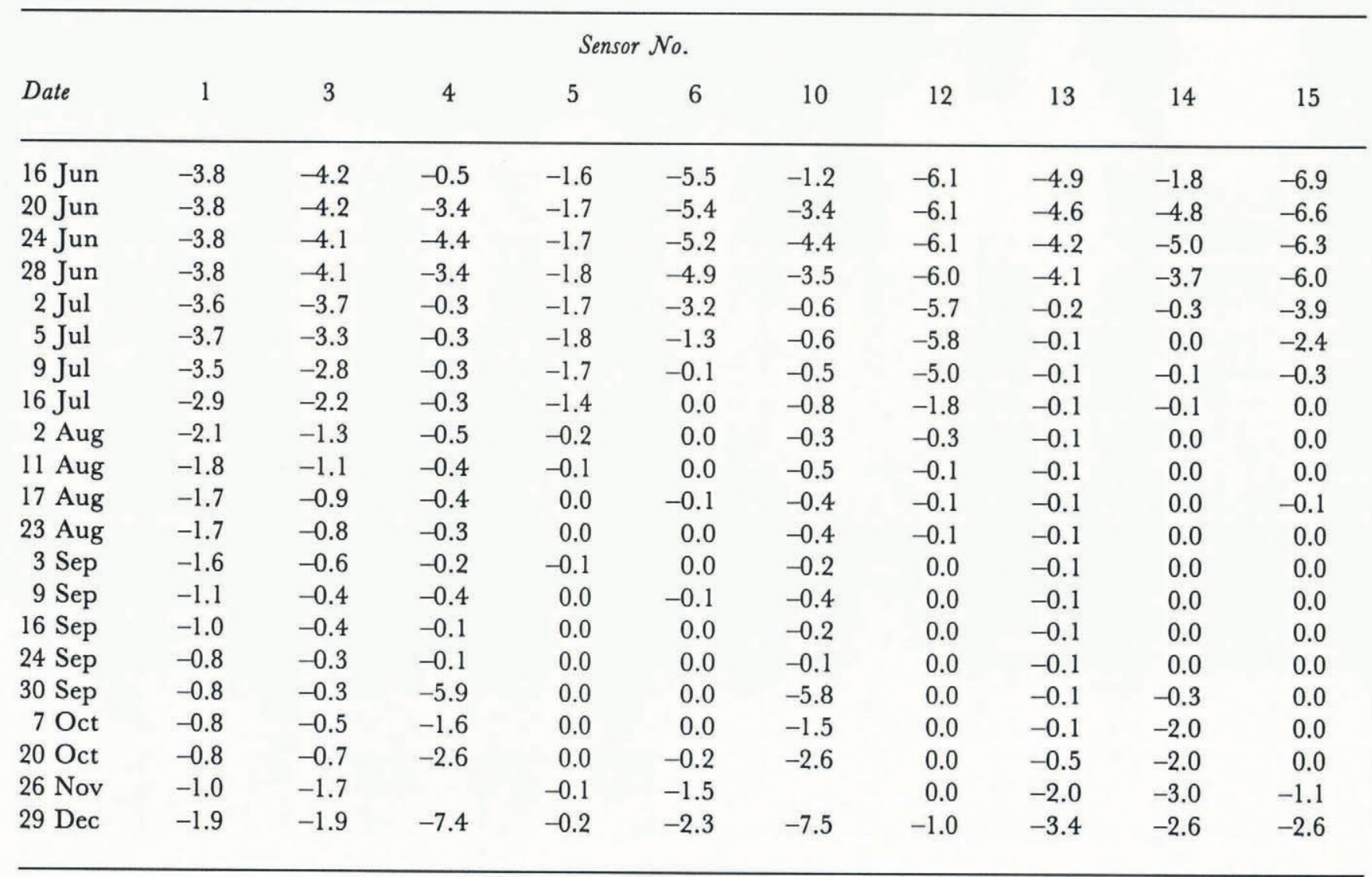




\begin{tabular}{|c|c|c|c|c|}
\hline \multirow[b]{2}{*}{ Date } & \multicolumn{2}{|c|}{ Distance travelled since 11 August } & \multicolumn{2}{|c|}{ Mean velocity } \\
\hline & $\begin{array}{l}\text { above schrund } \\
\mathrm{cm}\end{array}$ & $\begin{array}{l}\text { below schrund } \\
\mathrm{cm}\end{array}$ & $\begin{array}{l}\text { above schrund } \\
\qquad \mathrm{cm} \mathrm{d}^{-1}\end{array}$ & $\begin{array}{l}\text { below schrund } \\
\mathrm{cm} \mathrm{d}^{-1}\end{array}$ \\
\hline 11 August & 0.0 & 0.0 & 1.1 & 1.9 \\
\hline 17 August & 6.6 & 11.3 & 0.9 & 3.7 \\
\hline 23 August & 12.3 & 33.2 & 0.8 & 3.4 \\
\hline 3 September & 21.6 & 70.5 & 1.8 & 4.5 \\
\hline 9 September & 32.3 & 97.3 & 1.5 & 4.6 \\
\hline 16 September & 42.9 & 129.3 & 1.6 & 2.3 \\
\hline 24 September & 55.9 & 147.6 & 1.1 & 1.5 \\
\hline 30 September & 62.4 & 156.7 & & \\
\hline
\end{tabular}

\section{ICE MOVEMENT}

The kryokinometer records are presented in Table 2. The motion of a stake on the glacier surface is the result both of deformation of the ice and of its sliding over the bedrock or basal till. If the scalar value of the sliding components is $u_{\mathrm{b}}$ and that of the surface velocity $u_{\mathrm{B}}$, their difference is due to ice deformation. From an integration of Glen's law

$$
u_{\mathrm{s}}-u_{\mathrm{b}}=2 A \tau_{\mathrm{b}}{ }^{\mathrm{n}} h /(n+1)
$$

where $h$ is the ice thickness. $\tau_{\mathrm{b}}$ is the basal shear stress, $n$ is close to 3 and $A=5.3 \times 10^{-24} \mathrm{~Pa}^{-3} \mathrm{~s}^{-1}$ at $0^{\circ} \mathrm{C}$, according to Paterson (1981). The value of the basal shear stress is close to $1 \mathrm{bar}\left(10^{5} \mathrm{~Pa}\right)$ in many temperate glaciers and can be computed from surface slope $\alpha$ and ice thickness $h$ as

$$
\tau_{\mathrm{b}}=-\rho g h \sin \alpha
$$

$g$ being the acceleration of gravity and $\rho$ the density of the ice.

From Equations (1) and (2) one can evaluate the respective magnitudes of the sliding and deformation components of the observed surface velocity $u_{8}$. Ice depth at the upper stake was measured at $15 \mathrm{~m}$; that at the lower stake was estimated at $30 \mathrm{~m}$ from the observed depth of the bergschrund of $25 \mathrm{~m}$. Using $\rho=900 \mathrm{~kg} \mathrm{~m}^{-3}$ and the observed value of surface slope $a=32^{\circ}$, one obtains the results in Table 3.

These calculations use the assumption that there were no lateral or longitudinal stress gradients, based on the experience that many phenomena of glacier mechanics can be explained or at least approximated using the simple model of a parallel-sided, inclined slab which is easy to treat analytically (Schweizer, 1985). The change of the coefficient $A$ with temperature was neglected. Recognizing that on a seasonal average the ice below the bergschrund is colder than that above, one has to reduce the value of $A$ in Equation (1) (at $T=-5^{\circ} \mathrm{C}$ it would be only $30 \%$ of its value at the melting point). Compared to the observed surface velocity, this would mean that very likely the true value of $u_{\mathrm{b}}$ below the bergschrund is higher than that above. This conclusion is consistent with the concept of divergent, extending flow in that area of the glacier.

\section{THE RANDKLUFT}

A randkluft, or gap between headwall and ice, was observed at the measuring site. On 30 September it had opened to an average width of $60 \mathrm{~cm}$ as measured in the downslope direction. This value is nearly identical with the distance traveled by the upper kryokinometer stake and hence it can be concluded that the widening of the randkluft was predominantly due to basal sliding. This conclusion is supported by two observations: that the gap was somewhat wider near the base than at the surface,

Table 3. Data from above and below the bergschrund at Daunferner

\begin{tabular}{llll}
\hline $\begin{array}{c}\text { Above } \\
\text { bergschrund }\end{array}$ & $\begin{array}{c}\text { Below } \\
\text { bergschrund }\end{array}$ & \multicolumn{1}{c}{ Method } \\
\hline$h$ & $15 \mathrm{~m}$ & $30 \mathrm{~m}$ & Measured/estimated \\
$\alpha$ & $32^{\circ}$ & $32^{\circ}$ & Measured \\
$\tau_{\mathrm{b}}$ & $0.7 \mathrm{bar}$ & $1.4 \mathrm{bar}$ & From Equation (2) \\
$u_{\mathrm{s}}$ & $1.3 \mathrm{~cm} \mathrm{~d}^{-1}$ & $3.1 \mathrm{~cm} \mathrm{~d}^{-1}$ & Measured \\
$u_{\mathrm{b}}$ & $1.2 \mathrm{~cm} \mathrm{~d}^{-1}$ & $1.2 \mathrm{~cm} \mathrm{~d}^{-1}$ & $\begin{array}{l}\text { From Equation (1) } \\
\text { with constant } A\end{array}$ \\
& & &
\end{tabular}

$1.2<u_{\mathrm{b}}<2.4 \mathrm{~cm} \mathrm{~d}^{-1}$ for ice temperatures $0^{\circ}$ to $-5^{\circ} \mathrm{C}$. 
whereas melting by infrared radiation from the rock could have been effective only near the surface; and that the rock within the randkluft was partly covered with ice or snow even at times when the gap was widening.

\section{CONCLUSIONS}

Taking into account measured temperature distribution and measured surface-ice velocity, one can summarize the experiment as follows. At the site of investigations, the ice apron above the bergschrund was not frozen to the bedrock. At the beginning of August it was at the melting point throughout and was sliding at a seasonal mean rate of $1.2 \mathrm{~cm} \mathrm{~d}^{-1}$. The ice below the bergschrund had a cold core at $15 \mathrm{~m}$ depth but nonetheless must have been sliding, lubricated by meltwater that was observed to enter the bergschrund. The basal velocity of the ice below the crevasse was at least as high as that above; more likely it was $20-40 \%$ higher depending on assumptions made about the size of the cold core.

The surface velocity was observed to be more than twice as high below the bergschrund than above it. This was associated with a rapid increase of ice thickness at and in the vicinity of the crevasse, nearly doubling from $15 \mathrm{~m}$ at a location $5 \mathrm{~m}$ above to one $5 \mathrm{~m}$ below it.

Surface velocity was varying with air temperature, most likely via meltwater production and less likely via deformation rate. The distance of the two stakes above and below the bergschrund increased by $1.0 \mathrm{~m}$ in the $50 \mathrm{~d}$ from 11 August to 30 September. Adding about $1 \mathrm{~m}$ of ablation on either wall of the crevasse, the total widening of the gap was in excess of $3 \mathrm{~m}$. For the development of a bergschrund, ice dynamics are the principal cause. Only at a later stage may melting become of equal importance. Among the dynamical effects, basal gliding and the increase in deformation rate associated with an increase in ice thickness are of comparable magnitude.

At this location, the randkluft that separated the ice above the bergschrund from the headwall was without any doubt due to basal gliding of the ice whereas melting at the rock-ice interface can be ruled out.

\section{AGKNOWLEDGEMENTS}

The authors wish to thank the staff of Stubaier Gletscherbahnen AG for their support of the fieldwork. This study was financially supported by Kommission für Hochalpine Forschung of the Austrian Academy of Sciences under the late Professor F. Steinhauser.

\section{REFERENCES}

Gardner, J. S. 1987. Evidence for headwall weathering zones, Boundary Glacier, Canadian Rocky Mountains. J. Glaciol., 33(113), 60-67.

Haeberli, W. 1976. Eistemperaturen in den Alpen. Z. Gletscherkd. Glazialgeol., 11(2), 1975, 203-220.

Hanson, B. and R. LeB. Hooke. 1994. Short-term velocity variations and basal coupling near a bergschrund, Storglaciären, Sweden. F. Glaciol., 40(134), 67-74.

Klebelsberg, R.von. 1948-49. Handbuch der Gletscherkunde und Glazialgeologie. Erster Band. Allgemeiner Teil. Zweiter Band. Historisch-regionaler Teil. Wien, Springer-Verlag.

Mair, R. 1988. Temperatur- und Bewegungsmessungen an einem Bergschrund. (Thesis, Universität Innsbruck. Institut für Meteorologie und Geophysik.)

Markl, G. and H.P. Wagner. 1978. Messungen von Eis- und Firntemperaturen am Hintereisferner (Ötztaler Alpen). Z. Gletscherkd. Glazialgeol., 13(1-2), 1977, 261-265.

Osborn, G. 1983. Characteristics of the bergschrund of an avalanchecone glacier in the Canadian Rocky Mountains. J. Glaciol., 29(101), 55-69.

Paterson, W. S. B. 1981. The physics of glaciers. Second edition. Oxford, etc., Pergamon Press.

Schweizer, J. 1985. Untersuchung der Spannungs- und der Geschwindigkeitsverteilung eines steilen, am Bett festgefrorenen Gletschers. (Diplomarbeit Thesis, Eidgenössische Technische Hochschule, Zürich. Versuchsanstalt für Wasserbau, Hydrologie und Glaziologie.)

The accuracy of references in the text and in this list is the responsibility of the authors, to whom queries should be addressed. 